\title{
China’s Growth and Its Effects on Taiwan: What Does the Future Hold
}

\author{
Pei-Chun (Petrina) Feng \\ Central Police University, Taoyuan City, Taiwan
}

\begin{abstract}
In the study, the researcher investigated the strategy that has been behind China's growth. It has been found that China was using a "smile strategy". The strategy is to ensure peaceful co-existence between China and its neighbors. China had used this strategy to connect with most of its neighbors to encourage business, trade, and investment. Globalization has played a crucial role in the growth and development of China. China has always encouraged globalization and has connected with some of the countries in the neighborhood. This is because it depends on foreign investments for half of its imports and exports. Also, Taiwan and China have very tight economic ties. They depend on each other for economic development and Taiwan is among China's top business partners. In future, China plans to establish more links across the world that will enable it to develop economically. It is also expected to rise as a superpower and work with the rest of the superpowers in decision-making on issues affecting the world.
\end{abstract}

Keywords: China growth, economic growth, smile strategy

The power shift is a subject that has attracted a lot of discussion in the recent years. The Western countries have been the superpowers and are said to control the world. However, a power shift is not always welcomed especially by the superpower. It is because, it means that those countries will have to share their power to another state, and decision-making will also have to include another member (Acharya, 2014). China is in the East and has been growing at a very high rate. However, the growth is being dragged by some factors such as conflicts with its neighbors. Most of those conflicts have been due to territorial rights. China has changed some of the policies such having a less threatening military face so as to encourage trade and investment with the neighboring countries (Ahuja \& Nabar, 2012). One of its biggest business partners is Taiwan, which was once ruled by Republic of China after Japan. Despite the vigorous political differences, the two have created an excellent business environment. Taiwan has heavily invested in China, therefore playing a great role in its growth and development. Globalization has also played a significant role in the development of China (Wei \& Liefner, 2012). This has been mainly through foreign investments, tourism, and increased competition. This paper discusses China's growth, its effect on Taiwan, and the future expectations.

\section{Aim and Objectives}

China is among the best performing countries in Asia, the researcher would like to know the secret behind

Corresponding author: Pei-Chun (Petrina) Feng, Ph.D., professor, Administration Management Department, Central Police University, Taiwan; research fields: public administration, business ethics, public budgeting, behavior accounting, police policy, governmental procurement, human resource management, government-business relations, public-private partnerships, and non-profit organizations. E-mail: petrina1115@gmail.com. 
their success. China has had a lot of conflicts with different states in the world. The study tends to investigate the primary cause of the conflict. In order to achieve this aim, the following objectives must be met:

(1) To investigate more about China's past relationship with its neighbors. The researcher will also examine if the relationship has changed;

(2) To research various economic benefits that were felt by China due to the change;

(3) To find out the challenges to growth and how China is dealing with them. China has had several challenges, which have dragged it behind in growth and development;

(4) To investigate if their conflict has affected any other state. Despite the conflicts between China and Taiwan, they have been able to interact businesswise;

(5) To investigate the mutual benefits between the two states;

(6) To investigate how globalization has affected the development and growth of China will also be a subject that will be tackled.

\section{Literature Review}

\section{Strategy Behind China's Growth}

China has been known to be in conflict with its neighbors for a long time. The cause of these conflicts has been due to the territorial rights (Jean, Tan, \& Sinkovics, 2011). This has caused China to have a poor relationship with its neighbors, and they rarely conduct any business deals with one another. In the recent years, China has moved to a more peaceful strategy, commonly known as the "smile strategy". This strategy has since yielded more fruits than the traditional approach through economic growth. China's new approach is trying to meet the interest of its neighboring countries through trade and investments. The biggest challenge is that United States has most of the Chinese neighbors being its trade partners. These include: Taiwan, Japan, and South Korea. The three states are very productive, and this is the primary reason for United States remaining as a super power for a long time (Storey, 2015).

China has offered forth a less threatening military face to that it is the neighbor in the aim of displacing the United States. In the recent years, efforts have been made by China to be cautious about Taiwan, which has been a major threat to China. Taiwan has made an estimate of around $\$ 65$ to $\$ 150$ billion investment in coastal part of China (Wei, Zhou, Sun, \& Lin, 2012). Despite the substantial investment it has in China, the two have commonly disagreed especially on matters regarding territory and political issues. China has also invested highly in other states. In the study done by Brandt, Ma, and Rawski (2012) in 2011, it showed that China relies on foreign invested enterprises for about half of its imports and exports. This means that decisions made by those countries can directly influence the economic status of China. For example, taxes charged by those countries for imports and exports can create excellent trade relations between the two nations. Countries will tend to discourage imports by highly taxing them so that the locals can use the locally produced substitutes. It is, therefore, important for China to have a good relationship with the rest of the world. This ensures good inflows and outflows of goods and services in and out of the country (Baylis, Smith, \& Owens, 2013).

\section{Role of Globalization in Growth of China}

Today's world is a globalization-oriented world. Globalization directly or indirectly influences every country in the world in one way or another. The word globalization means integration achieved by interchanging products, world views, and ideas from the different parts of the world (Baylis et al., 2013). There is a flow of 
knowledge and money among various countries, and this can go beyond geographical boundaries. Goods and services produced by one country are consumed all over the world. This concept is referred to as globalization. Globalization links various countries to bring about global economic growth. Globalization brings about probabilities and profits with it, but this depends on the nation in question. The benefits of globalization have been realized in many countries like China. China has adopted a domestic strategy that permits its civilians to promote global market that helps in increasing China's gross domestic product (GDP). Globalization has both some positive and negative results, in this section, we are going to look at the role of globalization in the growth of China (Jean et al., 2011).

China is rapidly transforming itself into an economic superpower. This is contributed by the fact that Chinese companies are getting stronger and bigger; all these factors have led to an increase in GDP among the Chinese population (Wei \& Liefner, 2012). Globalization has resulted in the growth of the Chinese economy by double digits; this is because globalization leads in an export driven high GDP with the help of the readily available cheap Chinese labor. However, this has the disadvantage of locking the Chinese enterprise on the low-end of the global value chain which prevents advancement in technology (Peng, 2012).

Globalization has brought about positive competition in China and also the entire world. This competition either eliminates inefficient state-owned enterprises or makes them more competitive. The competition also brings about transparency in the Chinese economy which makes China more accessible to foreign influences. Competition ensures production of high-quality goods at an affordable price for the consumer (Baylis et al., 2013).

Globalization has brought about increased job opportunities that go hand in hand with improved lifestyle. Globalization has led to the creation of employment opportunities not only for the Chinese people but also to the entire world. Availability of jobs increases the ability of the people to afford basic goods and services, which result in lifestyle improvement (Blum, Sudhinaraset, \& Emerson, 2012).

Globalization has resulted in improved tourism, export, and import. In 2003, China was granted membership in the World Trade Organization (WTO) (Peng, 2012). This made China more attractive to both tourists and also investors from all over the world. This is evident through the high number of investors who have chosen China as their destiny for their businesses. China's membership in the WTO resulted in an increase of around $32.3 \%$ in exports and $40.5 \%$ of imports, the tourism industry also recorded a $9.7 \%$ increase (Crossley \& Bennett, 2007).

Globalization has also led to China's economic development. The population of the poor in China has been on the decline for the past 23 years (Jean et al., 2011). Industrialization of China has led to the creation of million jobs to its population and therefore bringing about sustainability.

\section{Economic Ties and Relationship Between China and Taiwan}

Taiwan is located 100 miles off the coast of China from the southern part of the China Sea. Republic of China ruled Taiwan for four years after Japan (Tucker \& Glaser, 2011). China and Taiwan have been in conflict for the last few years. This is because Taiwan feels that it should be an independent country while China, on the other hand, feels that Taiwan should be part of it. This has resulted in conflicts that have caused several attacks between both countries. The poor relations between China and Taiwan have also caused China and the United States to conflict, which in turn has resulted in trade relation's complexity. Taiwan imported most of its weapons from United States. These weapons are advanced and use the latest technology. United States is a superpower nation and is well-recognized for its well-developed weapons. In a research done by Tucker and 
Glaser (2011), it showed that between the year 2000 and 2007, Taiwan had received arms worth $\$ 8.4$ billion from U.S. The United States government had also stated that they would support Taiwan until China leaves it alone. The support given by the United States could have been aimed at winning Taiwan's loyalty in the future business ventures. On the other hand, China has used ballistic missiles and explosive along the Taiwan Strait. It is working hard to ensures that it improves and modernizes its missile forces and attack capabilities (Hsieh \& Sadoi, 2012).

Taiwan and China have tight economic ties. This is because China highly depends on imports and exports, and Taiwan has significantly invested in the coastal of China. By 2007, China was Taiwan's largest trading partner with 30\% of Taiwan's exports being sold to China. Similarly, Taiwan ranks top 10 among China's trading partners, making them to be very close when it comes to business. A research that was done by Chu and Kastner (2014) stated that since 1988, Taiwanese businesses have invested more than $\$ 150$ billion in the mainland of China. The two countries have agreed to allow banks, financial service providers, and insurers to work and invest in both markets so as to create a conducive working environment. This will create a mutual benefit for both states since the rules will be favoring both Taiwan and China. Trade barriers and restrictions are meant to control the rate of imports and exports (Torabi, 2015). There have been a few trade restrictions between the two states that have discouraged trade between them. For example, the changes in the Economic Cooperation Framework Agreement will ease trade restrictions. This can be achieved through frequent negotiations between the two states. Direct flights between China and Taiwan will profoundly increase business transaction between the two countries. In 2009, just after the introduction of direct flights, the flights between the two states increased from 108 to 207 per week (Jean et al., 2011). This was a significant improvement.

\section{Impact of Growth of China on Taiwan}

China and Taiwan have maintained a fragile relationship; periodic diplomatic patchworks have kept the Taiwan-island separate from the communist mainland of China since the year 1949 (Rowen, 2014). However, both China and Taiwan have experienced rapid economic growth for more than three decades. The economic growths of China and Taiwan have become ever more symbiotic over the years despite the ups and downs involved. In the year 2009, China’s GDP was reported at $\$ 4.9$ trillion which is the same as $\$ 3,680$ per capita. Taiwan's GDP was $\$ 370$ billion which results to an impressive $\$ 16,422$ per capita (Jean et al., 2011). This is due to Taiwan's lower population when compared with China. China and Taiwan have experienced similar globalization levels that have led them closer to one another.

There is a growing interdependence between the economy of China and that of Taiwan. However, the interdependence is not symmetric since China is more open to Taiwanese trade, investments, and labor (Brandt et al., 2012). Taiwan remains restrictive toward similar flows from China. Concurrent trade as a share of all trade and GDP has continuously grown since the year 1980 from Taiwan to China and since 2000, it has grown from China to Taiwan, this was before hitting a global financial crisis wall in 2008 (Peng, 2012). The trade is now recovering quickly.

Investments from Taiwan to China have hugely resulted in the redevelopment of the relationship between China and Taiwan (Brandt et al., 2012). Since earlier days of reform, most of Taiwan's investments were routed through Hong Kong and other nearby locations. Investments from China to Taiwan, on the other hand, have been strictly limited by the unreadiness of both parties. However, these limitations are under revision, and genuine concurrent investments are expected to grow significantly, the balance of openness is however 
expected to favor Taiwanese outflows for some time (Blum et al., 2012). The portfolio investments restrictions are also true, it gives investors from both sides a chance to invest in stocks, bonds, and securities issued by others. The movement of people across the Taiwanese Strait is growing rapidly though it is highly imbalanced. The number of Taiwanese visiting and working in China is very high when compared with the number of permanent residents and visitors from China to Taiwan. Normalization of long-stymied direct transport links and tourism policies is increasingly widening the base of concurrent exchanges beyond business interest to civic individuals and groups (Rowen, 2014).

The organic upward economic growth interaction of more than 20 years occurred despite obstacles to commerce and political tensions between China and Taiwan (Wei et al., 2012). In the recent past, stepped-up ad hoc negotiations have fastened the pace of economic integration and begun to formalize quasi-official methods to undergird concurrent commerce. However, the effectiveness of the ad hoc method is on the decline and more comprehensive tactic to cross-strait economics is past due (Wei \& Liefner, 2012).

\section{Methodology}

The study only used secondary research. Secondary research is a method that collects information that had been previously collected from primary research (Bryman, 2012). In this study, data were collected from books, magazines, articles, and journals. The researcher preferred to use secondary sources because they were inexpensive, readily available, and in some cases, they were the only sources of such information (Bryman, 2012).

The data collected were classified into two major categories. We have the internal secondary data and the external secondary data (O’Leary, 2013). Internal secondary data were data that were collected within the area of study. For example, data that were collected in regards to China and Taiwan. On the other hand, external secondary data were data that were collected outside the area of study (Yang, 2014), for example, data related to China's neighbors. Such data may not be in the field of study, but they contribute a lot to the success of internal secondary data.

The research was carried out in four major steps. The first step was to identify and acquire information concerning the subject of study (Morrow, Boddy, \& Lamb, 2014). The second step was to gather existing information, while the third step was to compare information from different sources, and the final step was to analyze the information that had been collected. The researcher first had to identify the subject that she wanted to research about. This includes the aim and objectives of the study. Later, the researcher had to search for data from different sources. This includes the hard copies from the libraries and the soft copies from the web. There were several sources that provided similar sources (Schmitz, 2014). Therefore, the researcher had to compare data from various sources so that she could collect relevant data. In this stage, the researcher normalized research data by year, related subjected and clarity of the information. Finally, the researcher was left with the task of analyzing the data that had been collected. The data that were collected had to be analyzed such that and the researcher had to combine different ideas of various authors that had addressed a single issue (O'Leary, 2013).

\section{Findings}

The finding that was collected was grouped into three key points: Globalization and China, growth of China, and relationship between China and Taiwan. These key points are discussed below. 


\section{Globalization and China}

The review of literature has indicated that globalization has helped significantly in the growth of China. One of the benefits of globalization that they discussed is increased competition. Competition results in the production of high-quality goods and services that satisfy the consumer needs at an affordable price. The local and the foreign industries that provide similar or substitute products compete in the same market (Ahuja \& Nabar, 2012). Therefore, for a firm to improve their productivity and increase its profits, the firm must provide better quality of goods and services.

Globalization has also increased job opportunity and availability of wide variety of workforce. With globalization, labor force from all over the world is readily available. The firms and industries in China have access to labor from all over the world making it easier for them to operate. Easier access to the workforce makes it easier for the production process. Foreign investment done in China creates more job opportunities for the Chinese population. Once the organization has established its branches in a state, they provide employment to the people in the area who have the relevant qualifications (Baylis et al., 2013b). The government can also improvise some rules, in this case, rules that states; foreign organizations must employ a certain number of citizens before it employs outsiders.

\section{Growth of China}

As per the findings of literature survey, improved tourism, exports, and imports have been the core reason for the growth in China. People from all over the world visit China to experience the Chinese culture and see natural features. China benefits in that foreigners help boost the business in the country and also from the foreign exchange generated. It is through globalization that China can import and export from all over the world. This is through business transactions that are undertaken all over China and from the revenues that the government collects (Peng, 2012). This article also focuses on economic developments that are created by globalization.

China is using good relations with its neighbors as a strategy to improve on its growth. China has had several conflicts with its neighbors in the past. The conflicts have been due to territorial rights issues. This conflict has been mostly with Taiwan. China has however changed this strategy, and it is using another strategy called "smile strategy". The strategy aims at creating peace with most of the neighbors so that to encourage trade and investment among them. China is also offering a less threatening military face to all its neighbors except Taiwan (Hsieh \& Sadoi, 2012). This strategy has since been productive, and China has recorded the highest rate of growth rate ever.

Power shift from the West to the East is as a result of economic growth, wherein United States which is in the West and China which is in the East. In a study done in 2013, United States had a growth rate of 2.2\% per annum while China had a growth rate of 7.7\% per annum (Eichengreen, Park, \& Shin, 2012). This indicates that the growth rate of China is more than thrice that of United States. This means that if China continues with the same growth rate, they may be ahead of United States in a few years to come. The figure below shows that China for the last five years has always been having a growth rate of more than five while the growth rate of United States has been below five (see Figure 1). Therefore, China may soon be a superpower like the United States. It means that the power may shift from the West to the East.

\section{Relationship Between China and Taiwan}

Despite China and Taiwan being close neighbors, they have had conflicts with one another for the longest 
time. Republic of China ruled Taiwan for four years after Japan and had various political differences. The research indicates that despite their political difference, the two still conduct business together and are thriving for economic growth. Taiwan has invested heavily in China. This means that both countries depend on each other for survival. On the other hand, China depends on imports and exports from other countries. Therefore, they depend on each other for economic development. There have been negotiations meant to reduce trade restrictions that exist between the two nations. For example, the banks and financial institutions have been allowed to operate freely although both countries. Taiwan has played a great role in the development and growth of China. It is because Taiwan is in the top 10 list of the countries that China conducts business with.

This information has been collected by different authors who have compiled their research inform of a report, journal, or even a book. The research combines information from several books so as to understand the growth of China (Chang, Hu, Chou, \& Sun, 2012). The sources provide different factors that have led to the growth and also the challenges that it has encountered during the implementation of this strategy. The researchers also found out that despite the conflict that exists between China and Taiwan, the two countries share a lot in common. They depend on each other for development.



Figure 1. Showing growth rate of China and United States. Source: Eichengreen et al. (2012).

\section{Conclusions and Discussions}

China is among the few countries in the East that has experienced a high economic growth. A study done in 2013 shows that China has thrice the growth rate of United States. The secret behind this growth has been to create peaceful relationships with its neighbors. This makes it easier for other countries to perform trade and investments partnering with China. Globalization has also played a significant role in the growth of China. Taiwan has a close business relation with China and has invested heavily in China. There is an interdependence between the growth of China and Taiwan. This is due to the various investments Taiwan has invested in China and the various business transactions both states do. In future, China is expected to be among the superpowers (Ahuja \& Nabar, 2012). This is due to its high economic growth rate. It is also expected that it will engage in business with companies from all over the world. This will ensure an increase in the economic growth. 


\section{References}

Acharya, A. (2014). Power shift or paradigm shift? China's rise and Asia's emerging security order. International Studies Quarterly, 58(1), 158-173.

Ahuja, A., \& Nabar, M. (2012). Investment-led growth in China: Global spillovers. Working Paper No. WP/12/267. Retrieved from http://papers.ssrn.com/sol3/papers.cfm?abstract_id=2191312

Baylis, J., Smith, S., \& Owens, P. (2013). The globalization of world politics: An introduction to international relations. UK: Oxford University Press.

Blum, R., Sudhinaraset, M., \& Emerson, M. (2012). Youth at risk: Suicidal thoughts and attempts in Vietnam, China, and Taiwan. Journal of Adolescent Health, 50(3), 37-44.

Brandt, L., Ma, D., \& Rawski, T. (2012). From divergence to convergence: Re-evaluating the history behind China's economic boom. Journal of Economic Literature, 52(1), 45-123.

Bryman, A. (2012). Social research methods. UK: Oxford University.

Chang, T., Hu, J., Chou, R., \& Sun, L. (2012). The sources of bank productivity growth in China during 2002-2009: A disaggregation view. Journal of Banking \& Finance, 36(7), 1997-2006.

Chu, M., \& Kastner, S. (2014). Globalization and security relations across the Taiwan Strait: In the shadow of China. NY: Routledge.

Crossley, C., \& Bennett, R. (2007). Development of a global measure of job embeddedness and integration into a traditional model of voluntary turnover. Journal of Applied Psychology, 92(4), 1031-1042.

Eichengreen, B., Park, D., \& Shin, K. (2012). When fast-growing economies slow down: International evidence and implications for China. Asian Economic Papers, 11(1), 42-87.

Hsieh, K., \& Sadoi, Y. (2012). Changes in triangular economic relations between Japan, China and Taiwan in the 21st century. The Meijo Review, 13(2), 1-18.

Jean, R., Tan, D., \& Sinkovics, R. (2011). Ethnic ties, location choice, and firm performance in foreign direct investment: A study of Taiwanese business groups FDI in China. International Business Review, 20(6), 627-635.

Morrow, V., Boddy, J., \& Lamb, R. (2014). The ethics of secondary data analysis: Learning from the experience of sharing qualitative data from young people and their families in an international study of childhood proverty. London: Novella.

O’Leary, D. E. (2013). Exploiting big data from mobile device sensor-based Apps: Challenges and benefits. MISQE, 12(4), 179-187.

Peng, M. W. (2012). The global strategy of emerging multinationals from China. Journal of Global Strategy, 2, 97-107.

Rowen, I. (2014). Tourism as a territorial strategy: The case of China and Taiwan. Annals of Tourism Research. Retrieved from http://www.sciencedirect.com/science/article/pii/S0160738314000255

Schmitz, H. (2014). How does the global power shift affect the low carbon transformation? Brighton: Institute of Development Studies.

Storey, I. (2015). The United States and ASEAN-China relations: All quiet on the Southeast Asian front. Pennsylyania: The Strategic Studies of the U.S. Army War College.

Torabi, G. (2015). Uncharted strait. The future of China-Taiwan relations. Europe-Asia Studies, 67(4), 687-688.

Tucker, N., \& Glaser, B. (2011). Should the United States abandon Taiwan? The Washington Quarterly, 34(4), 23-24.

Wei, Y., \& Liefner, I. (2012). Globalization, industrial restructuring, and regional development in China. Applied Geography, 32(1), 102-184.

Wei, Y., Zhou, Y., Sun, Y., \& Lin, G. (2012). Production and R\&D networks of foreign ventures in China: Implications for technological dynamism and regional development. Applied Geography, 32(1), 106-118.

Yang, Z. (2014). What did they say and why did they say so?-Slogans in 2012 anti-Japanese demonstrations and discourse of contemporary Chinese nationalists. Retrieved from http://openaccess.leidenuniv.nl/handle/1887/29522 